\title{
Evaluation Of Policy And Legal Environment For The Management Of Coastal Zones In Ghana With Special Emphasis On Bukom, A Coastal Suburb Of Accra District
}

\author{
Feizel Ayitey Aryee \\ Mphil Environmental Management School Of Public Leadership Stellenbosch University Matieland, \\ Stellenbosch South Africa
}

\begin{abstract}
The world's population is increasing at an exponential level and coupled with rural-urban migration and other detrimental activities of human beings, the Earth's natural resources is constantly being subjected to intense negative pressures. These pressures have contributed immensely to the degradation of the environment especially the coastal zones. Ghana as a coastal zone country is not spared this global degradation. Ghana is home to one of the largest artificial lakes in the world, the lake Bosomtwe. The country is widely known for famous rivers, lagoons, estuaries and the country generates most of its income from tourism activities. It is therefore expedient that the country should promulgate and implement policies that will help protect its coastal resources to ensure sustainable use of the coastal and marine zones. This paper reviews the availability of an Integrated Coastal Management Policy in Ghana and how it is been implemented to ensure sustainability. At the end of the research, it was concluded that Ghana has no coastal zone policy and this has resulted in the overexploration of coastal resources. Bokum, a typical coastal town in Accra was used as a case study. Most residents interviewed showed no knowledge of coastal zone distraction at all. Ghana has to promulgate and implement coastal zones policy as soon as possible to ensure that resources are not over-exploited but they are managed in a sustainable manner to ensure that future generation are not deprive of their fair share of coastal zone resources.
\end{abstract}

Keywords: coastal zone, policy evaluation, sustainable development, Bukom, Ghana

\section{Introduction}

The world's population has experienced an unexpected continuous growth since the end of the Black Death and the great famine of 1350. In 1350 the world's population was estimated to be around 370 million (Biraben, 1980). Currently, the United States Census Bureau estimates the world's population on $12^{\text {th }}$ March 2012 to have exceeded 7 billion people. This current population growth is alarming with Ghana being a developing nation is faced with such situation of increase in the population of the country. The current population of Ghana as released by the Ghana Statistic Service (2010) stands at 24 million. The total land cover of Ghana is $238533 \mathrm{~km}^{2}$ and out of this, $550 \mathrm{~km}$ is coastlines. Available statistics as referenced from Churcher (2006) indicate that this 7 per cent of Ghana's coastline is home to 25 per cent of the nation's population and it is also where 75 per cent of Ghana's industry is located. What is alarming is the fact that 51.5 per cent of these coastal regions is urbanised as compared with the national 35.4 per cent urbanised areas.

The rate of unemployment in Ghana is also very high due to the fact that the number of graduates from the various universities in a year far exceeds the annual rate of job creation. Ghana is bordered by the Atlantic Ocean in the southern part of the country. This has created employment in these coastal regions as fishing activities has boomed. There are also two harbours in the country, namely the Tema Harbour and the Takoradi Harbour. These two harbours as well as activities along the coastal regions have created so many opportunities for the country. Due to the rate of increase in Ghana's population, the pressure on the country's coastal zones is very alarming as most Ghanaians from the other regions of the country troop to these coastal regions to seek employment and also to engage in other activities in order to generate income. Flooding, shoreline retreat and coastal erosions are part of the major negative impacts along Ghana's coastline (Ly, 1980).

In Hardin's book, the "The tragedy of the commons", Hardin explained vividly how a common good which is mutually shared can be over-exploited to destruction (Hardin, 1968). This situation is paramount in Ghana's situation and it is unbearable as to the kind of human activities taking place in the country's coastal region or zones. Ghana being a signatory to Agenda 17 has the duty to promulgate and enforce laws to protect its coastal waters in a sustainable manner to be able to serve the current as well as the future generation.

This paper will therefore take a look at integrated coastal management policies in Ghana, how it is being implemented, challenges facing enforcing agencies and the way forward. Special focus will be given to a local coastal community in Ghana called Bukom. 


\section{Literature Review}

Increase in population especially rural - urban migration has resulted in an increase pressure on natural resources and this has increase pressure on the Earth's coastal zones. In view of this, various organisations have come up with approaches or solutions to help mitigate the destruction of the coastal zones. An approach used by various international organisations is the Integrated Coastal Management (ICM) approach. ICM is an approach that uses an integrated method and takes into consideration various factors that affects coastal zones including political and geographical boundaries. The main aim of ICM is the attainment of sustainability.

ICM as a management tool originated from the Earth Summit at Rio Janeiro in 1992. The procedures and mode of implementation of ICM is spelled out in a document that came out of the Rio Janeiro conference entitled Agenda 21. ICM policies can be found at chapter 17 of Agenda 21.

ICM is difficult to define due to the fuzziness of coastal zones in that it is difficult to demarcate coastal zones. Ketchum (1972) defined coastal zone as "The band of dry land and adjacent ocean space (water and submerged land) in which terrestrial processes and land uses directly affect oceanic processes and uses, and vice versa'. There are many dynamics that affects the oceans and there are various human activities which negatively affects the oceans. ICM is human management in that; it is human activities affecting the ocean that needs management and not the water bodies' per-say.

Coastal zones provide various uses for human and other living creatures therefore the need to preserve human activities that negatively affect coastal zones. Complex processes take place within the world's coastal zones and this creates productive ecosystems which have been of important use to human population (Kay \& Alder, 1999). The world's coastal zones equates to 8 per cent of the earth's surface area, this 8 per cent surface area provides for 25 per cent of the world's productivity. The pressure on the ocean zone is because about 70 per cent of the world's population are within a day's walk from oceans (Brown et. al., 2002). It is recorded that twothirds of the world's cities are located in the coast (Crooks \& Turner, 1999) and as have stated above, this has led to various human destruction of the coastal zones. Products from the oceans are considered to be a 'common property' for coastal communities. Fish and other mineral resources are in demand therefore the need for these resources to be adequately controlled in order to prevent over exploitation (Berkes, 1989). According to Brown et.al, (2002) common property perception of the coastal zones has led to a harvest of 90 per cent of the world's fish that are within the exclusive economic zones. The exclusive economic zones are zones around the ocean or coast that is within the sight of shore.

Sustainability is an important concept that is mutually inclusive with coastal zone management. Sustainability is a term coined in 1987 in the report of the World Commission on Environment and Development. This report defined sustainability as "the ability to meet the needs of the present without compromising the ability of future generations to meet their own needs". Sustainability is a way of thinking with long-term goals and aspirations and comes with corresponding responsibilities. In summary, sustainability takes into account the right of the present generation to live a healthy and productive life, allows for equal distribution of natural resources to the future generations and ultimately the protection of the environment through appropriate use of the available natural resources (Cicin-Sain, 1993).

Coastal zone management is a complex multi-facet phrase that incorporates various disciplines and the fact that it involves human management makes it very complex. Integration in the context of coastal zone management has both vertical and horizontal phases which need careful and accurate blending. Integration therefore forms an integral part of coastal zone management. Since coastal zones span various institutions and countries, Cicin-Sain (1993) identified five levels of integration that is of importance in coastal zone management and these are integration between nations, integration among levels of government, integration among sectors and finally integration between land and water elements of the coastal zone.

In addressing issues affecting coastal zone, it is necessary that management adopt a holistic and broad approach concerning factors that affect the coastal zones (Williams \& Micallef, 2009). As already stated, coastal zone issues are complex, therefore management framework should be applied to specific geographical location and the framework should be operated with high degree of integration (Hia-Eng, 1993). Though coastal zone issues are complex, common procedure for the establishment of management framework can be developed and applied. Four step approaches that can be applied includes: Firstly, the specific coastal zone issue has to be identified and quantified. This requires holistic integration between central governments, particularly ministry and local residents. Secondly, coastal zone management framework is drafted. Thirdly, the drafted management framework is adopted and the adoption can take two forms; it can either be statutory, that is, is legally binding or it can be non-statutory, not necessarily legal binding and can be a guide for future developments (Masselink $\&$ Hughes, 2003). The fourth step is the implementation stage which is an important part of the management framework formulation. The fourth stage includes education, law enforcement etc. Finally, the whole process has to be evaluated periodically because ICM is an ongoing process which should be evaluated to correct any shortcomings. This will establish a balance between protection of the environment and economic development. 
Clark (1996) defined policy as "prescribed course based on guiding principles adopted and followed by government, institution or an individual". Policy is an important tool that guides how laws should be implemented. The term policy may apply to various stakeholders such as government agencies, private corporations, NGOs etc. There are various methods for formulating policies in political science. Harod Lasswell proposed five stages of policy formulation. These stages are: Agenda setting, policy formulation, adoption, implementation and evaluation (Nakamura, 1987). Thus: policy formulation starts with identification of a particular problem or issue, followed by the problem being put into the public domain for thorough debate and discussion and the building of consensus. After the public participation phase, the policy is then formulated and the formulated policy is evaluated and reviewed. Policy formulation process is complex and involves many stakeholders each with different interest (Dudley, 1984). There are lot of time overlap, interactions and discontinuities in policy formulation processes.

An important phase of policy formulation is the evaluation phase. This paper reviews policy evaluation of Ghana's integrated coastal zone management policy, the rest of this paper therefore focuses on policy evaluation issues. Policies involve various stakeholders and may have intended and unintended consequences, there is therefore the need for every policy to be critically evaluated to ensure that positive attributes of the policy is enhanced whiles negative attributes are eliminated to the barest minimum. Trochim (2009) in his paper entitled "Evaluation Policy and Evaluation Practice" on page 4, defined policy evaluation as "Any rule or principle that a group or organization uses to guide its decisions and actions when doing evaluation".

Policy evaluations should be guided by a policy and an evaluation policy can be both written and explicit or it can be unwritten and implicit. It is recommended that evaluation policies should be written so it becomes available to various stakeholders. This will encourage transparency during the policy evaluation process. Besides policy evaluation being written down, it is recommended to be cooperative in nature; thus it should involve public participation and various stakeholders (Juma \& Clark, 1995).

Why is policy evaluation necessary or important? This paragraph will review the importance of policy evaluation and why every organisation should encourage it.

Policy evaluation is a signalling tool that signals or communicates to organisations how effective its policies are. It informs stakeholders who are responsible for what process, what exactly is wrong with the policy as well as areas that need improvement. Policy evaluation is an important communicating tool for policy makers and stakeholders who may have an interest in the policy. Secondly, policy evaluation process is cooperative in nature; it enables those affected by a policy have confidence in the policy because those affected by the policy are involve in the evaluation process and this bridges mistrust among the various players. Evaluation process brings transparency, accountability and a high sense of responsibility and an increase in productivity because everyone was involved in the evaluation process. Thirdly, evaluation of policies is a form of learning (Preskill, 2004). According to Preskill (2004), policy evaluation is a learning tool because policy is a dynamic process and when they are evaluated it brings out the shortcomings of the policy and ways to mitigate those shortcomings. Since this is dynamic in nature, it can be a major source of learning. Finally, policy evaluation is a major source of effecting policy change (Trochim, 2009). When a policy is evaluated and its shortcomings are made known, new policies can be formulated out of the old policy which is effective and proactive in nature than the previous policy.

Policy evaluation is an important component of policy formulation process. Policy evaluation should be a written document, it should be participatory in nature, thus it should involve various stakeholders, it should be flexible and highly adaptive and importantly, it should take into consideration the desires and needs of the current generation and also make sure the policy formulated does not hinder future generation from enjoying the rights and privileges being enjoyed by the current generation. In summary, every policy evaluation process should incorporate the principle of sustainable development as its backbone.

The next paragraph of this paper will focus on coastal zone policies in Ghana.

\section{Ghana's Coastal Zone Policy}

Coastal and marine zone policy in Ghana dates back to the $15^{\text {th }}$ century when European settlers first arrived at the then Gold Coast. International policies that emerged during the 1992 United Nations Conference on Environment and Development popular known as Agenda 21 greatly influenced and affected environmental and coastal zone policies in Ghana.

Agenda 21 did have a positive effect on general environmental management and policy promulgation and implementation in the world and Ghana is no exception. Ghana has no specific policy regarding integrated coastal zone management. However there are a number of related policies in Ghana that aims at coastal zone protection. Some of these policies are:

- National Wetlands Policy

- Tourism Development Policy

- National Health Policy 
- The National Environment Policy

- Agricultural Policy

- Mineral Policy

- Wildlife Conservation Policy

These policies are geared towards integrated coastal zone management, conservation and sustainable use of marine living resources and the protection of the marine and coastal environment. From the enactment of these policies, there has been definitive and concrete step that aims at better protecting the marine and coastal zones of the country. Some of the plans and strategies that have been enacted in Ghana include the following:

- National Environmental Action Plan (1994)

- $\quad$ Draft Integrated Coastal Zone Plan (1998)

- Coastal Zone Profile of Ghana

- Coastal Zone Management Indicative Plan (1990)

The legal frameworks for coastal zone management in Ghana are contain in the following documents:

- Environmental Protection Agency (EPA) Act (1994): Act 490

- The 1992 Constitution of Ghana

- Local Government Act, 1993 (Act 462)

- Environmental Standards and Guidelines

- Environmental Assessment Regulations

Ghana also has specific policies regulating specific sectors of the economy. The legal framework for the fisheries resources include

- $\quad$ PNDC law 256: Fisheries Law 1971

- Fisheries Act 2000

The legal framework regulating the protections of Ghana's ecosystem includes the following:

- Wetland Management Regulation, 1999 (Ramsar site)

- Wildlife Conservation Regulations 1971 (LI 685)

- Wild Animal Preservation Act 1961 (Act 43)

- Wild Reserves Regulation 1971 (LI 740)

In compliance with AGENDA 21 regulations, the country has undertaken various projects that aim at complying with the agenda of AGENDA 21. These projects are:

- $\quad$ Fisheries Sub-sector Capacity Building project

- $\quad$ Building of a Protected Wetland Ecosystem on the Coast of the country

- Ghana Environmental Resource Management Project in Coastal Wetland Management Component.

- Development of Industrial Pollution Standard

- Institution of a Program of Monitoring, Compliance and Surveillance of the marine environment.

- Development of industrial pollution standards

- There have also been increases in public education on effective marine and coastal environmental practise.

\section{Study Context And Methodology}

This research was based on the case study approach and the evaluation of primary and secondary data in its analysis and evaluation. Qualitative data was also analysed appropriately. This type of research is therefore participatory in nature

Ly (1980) described the features and characteristics of Ghana's coastal zones as:

* "Between Cape Three Points and Tema: this aspect is of an embayed coast of rock headlands and sandbars or spits enclosing coastal lagoons. The surf zone is high-energy environment with wave heights often exceeding 1 metre. The south-westerly prevailing winds cause oblique wave approach to the shoreline, which generates an eastward littoral sediment transport.

* West of Cape Three Points: a flat and wide beach, backed by coastal lagoons, marks this coast. Wave height is generally low.

* East of Tema: the shoreline is sandy and is characterised by the eroding Volta delta. Wave and sediment dynamics are similar to those between Cape Three Points and 
Tema.. It is known that rocky shores and rocky reefs are restricted to the area between Axim and Tema. It is also known that the rocky shores support a wide range of organisms in the intertidal zone,'. (Ly, 1980:323-332).

Figure 2.1 below illustrates the coastal zones of Ghana as illustrated by Ly (1980).

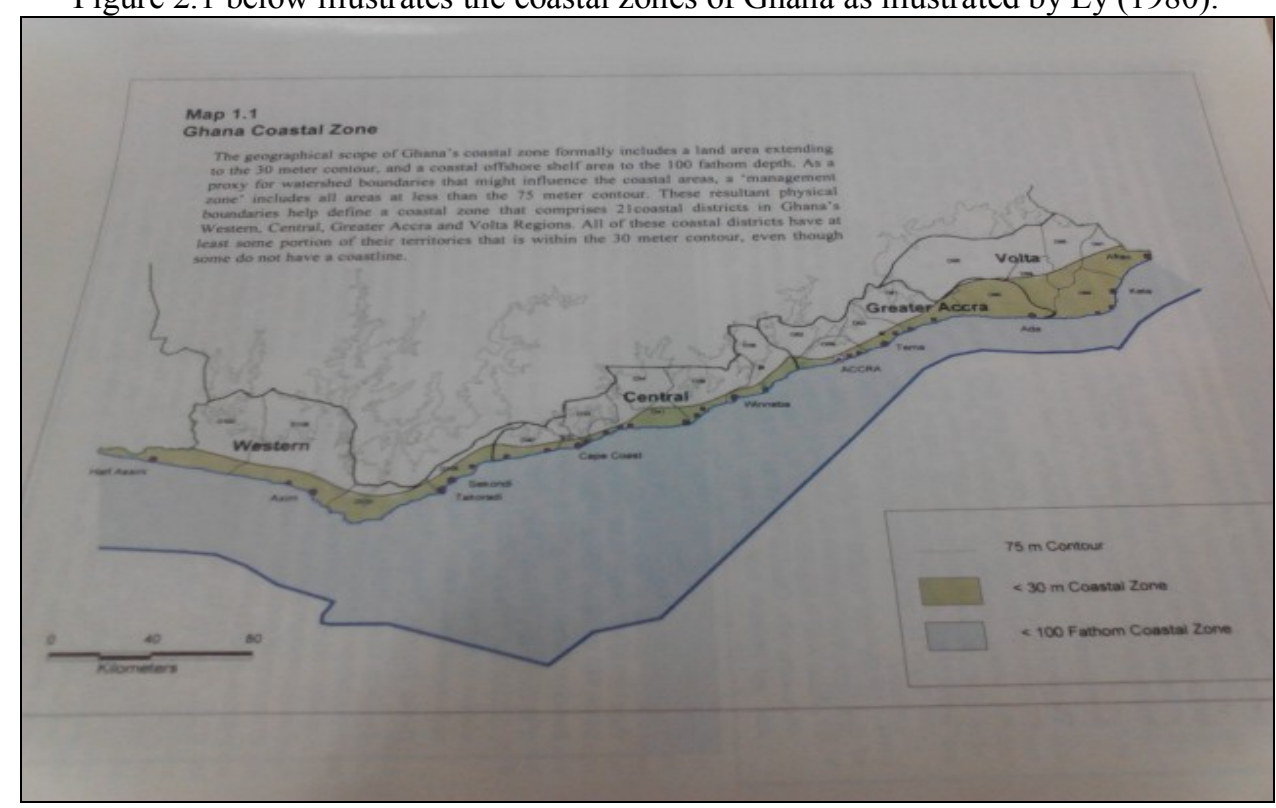

FIGURE 2.1: Coastal zones of Ghana Source: EPA, 1996)

Ghana's coastal zone as demonstrated in Figure 2.1 above is located in the southern part of the country. The southern part is surrounded by the Atlantic Ocean. From east to west as shown in Figure 2.1 the vegetation type reflects rainfall pattern ranging from coastal shrub and savannah, southern marginal forest, dry semideciduous, wet semi-deciduous to the east and wet ever-green forest to the extreme south-west (Western Region) of the country.

Ghana's coastal zone is rich in natural resources and host 25 per cent of the human population. The coastal zone is also home to about 80 per cent of Ghana's industries (Armah and Amlalo, 1998).

The primary commercial activity along Ghana's coastal zone is fishing. Other commercial activities are salt production, stone and sand winning, recreational activities, agriculture activities and more recently, there has been the discovery and exploration of oil and gas in the country at the Western Region of Ghana.

The geographical scope of Ghana's coastline includes a land area that extends to the 30m contour as well as a coastal offshore shelf area to the $100 \mathrm{~m}$ fathom depth. These physical boundaries helped define Ghana's coastal zone which includes 21 coastal districts. These twenty one districts have at least part of their territories that is within the $30 \mathrm{~m}$ contour while others do not have. Table 3.1 is a summary of the 21 coastal districts in Ghana and the rate of population density and urbanisation as at the year 1994.

Table 3.1: Summary of the 21 coastal districts in Ghana

\begin{tabular}{|c|c|c|c|c|c|c|c|c|}
\hline Code & District & Region & 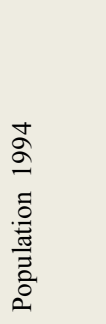 & 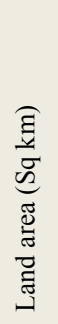 & 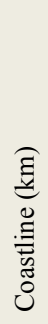 & 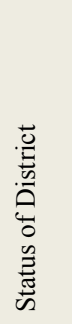 & 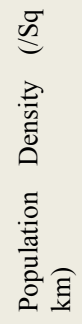 & 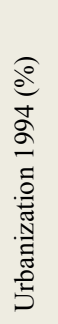 \\
\hline 037 & Cape Coast & Central & 118502 & 125 & 12 & Old & 948 & 26.0 \\
\hline 032 & Abura Asebu & Central & 46881 & 401 & 4 & New & 117 & 4.0 \\
\hline 041 & Mfantseman & Central & 187164 & 522 & 46 & Old & 359 & 10.0 \\
\hline 039 & Gomoa & Central & 184778 & 842 & 19 & New & 219 & 6.0 \\
\hline 038 & Ewutu-Efutu Senya & Central & 122402 & 713 & 39 & Old & 172 & 5.0 \\
\hline 034 & Ajumako Enyam Esiam & Central & 88580 & 458 & 0 & Old & 193 & 5.0 \\
\hline 040 & K. Edina Eguafo & Central & 105158 & 401 & 29 & New & 262 & 7.0 \\
\hline
\end{tabular}




\begin{tabular}{|c|c|c|c|c|c|c|c|c|}
\hline 062 & $\mathrm{Ga}$ & $\begin{array}{l}\text { Greater } \\
\text { Accra }\end{array}$ & 181660 & 562 & 0 & New & 323 & 70.0 \\
\hline 063 & Tema & $\begin{array}{l}\text { Greater } \\
\text { Accra }\end{array}$ & 260666 & 476 & 24 & Old & 548 & 50.0 \\
\hline Code & District & Region & 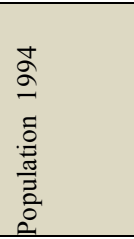 & 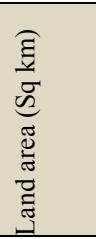 & 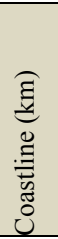 & 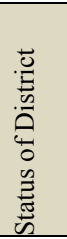 & 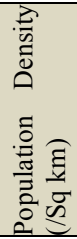 & 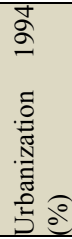 \\
\hline 061 & Dangbe West & $\begin{array}{l}\text { Greater } \\
\text { Accra }\end{array}$ & 86109 & 962 & 30 & New & 90 & 10.0 \\
\hline 060 & Dangbe East & $\begin{array}{l}\text { Greater } \\
\text { Accra }\end{array}$ & 94291 & 772 & 38 & Old & 122 & 15.0 \\
\hline 059 & Accra & $\begin{array}{l}\text { Greater } \\
\text { Accra }\end{array}$ & 1320021 & 345 & 34 & Old & 3826 & 100.0 \\
\hline 089 & Anlo & Volta & 151185 & 728 & 55 & Old & 208 & 56.0 \\
\hline 091 & Denu Dzodze & Volta & 245931 & 632 & 24 & Old & 389 & 32.0 \\
\hline 096 & Tongo $(\mathrm{N})$ & Volta & 135911 & 1836 & 0 & New & 74 & 13.0 \\
\hline 066 & Akatsi & Volta & 64576 & 900 & 0 & New & 72 & 0.0 \\
\hline 099 & Tongo (S) & Volta & 62430 & 503 & 0 & Old & 164 & 13.0 \\
\hline 0106 & Nzema East & Western & 113679 & 2088 & 51 & Old & 55 & 15.0 \\
\hline 0100 & Ahanta West & Western & 119016 & 568 & 57 & New & 210 & 0.0 \\
\hline 0106 & Ahanta East & Western & 306776 & 417 & 32 & Old & 736 & 69.0 \\
\hline D103 & Jomoro & Western & 58474 & 1350 & 55 & New & 66 & 12.4 \\
\hline \multicolumn{3}{|c|}{ TOTAL } & 4104392 & 15601 & 550 & & 263 & 51.5 \\
\hline
\end{tabular}

\section{Source: EPA, 1996}

This research utilises the case study approach in its analysis and evaluation. I spent two weeks obersving the local residents of Bukom and interviewing them as well. Below is the results of my interaction with them.

Bukom, a town located along the coast of the Accra District of the Greater Accra Region of Ghana. It is a tribal town dominated by the Ga people. The town is known for the production of famous boxers. Bukom is located along the coast and the inhabitants are either fishermen or fishmongers. The predominant food in this community is kenkey (corn made into dough and wrapped in leaf and steamed over dry heat) and fried fish. I took time off to visit this small town to assess the kind of activities going on along the coast of this primitive coastal town. of Bukom.

The Figures below show the occupation of the local residents and were taken 200 meters from the coast

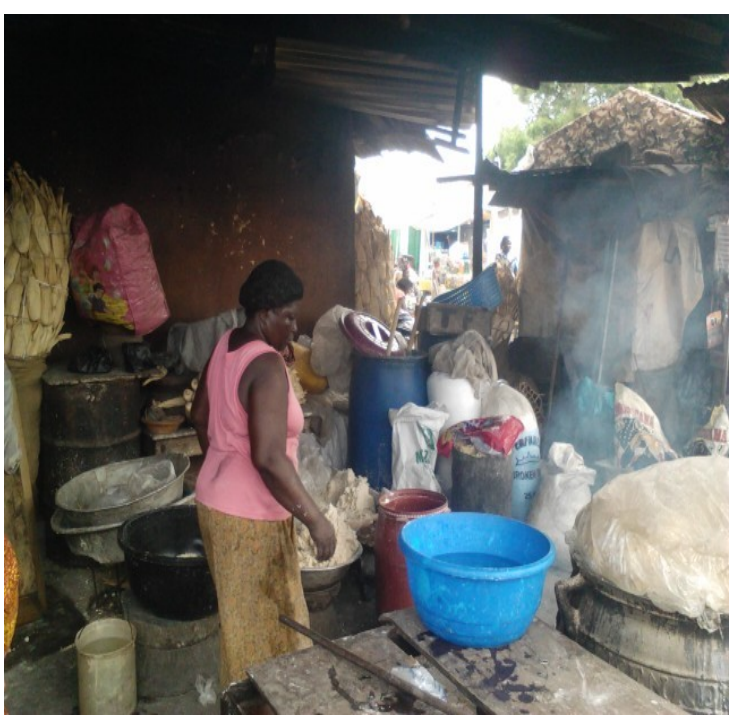

Picture 1: Women engaged in kenkey making in Bukom

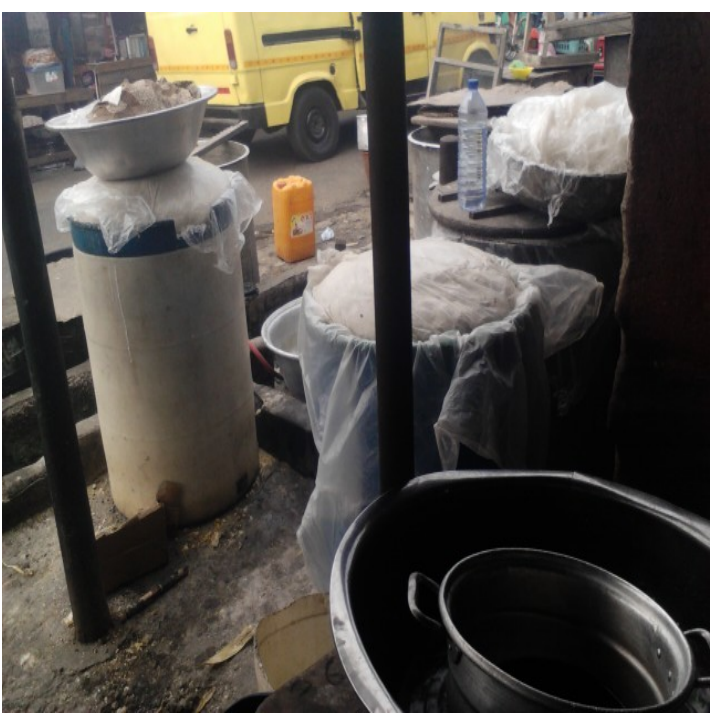

Picture .2: Utensils with corn dough 


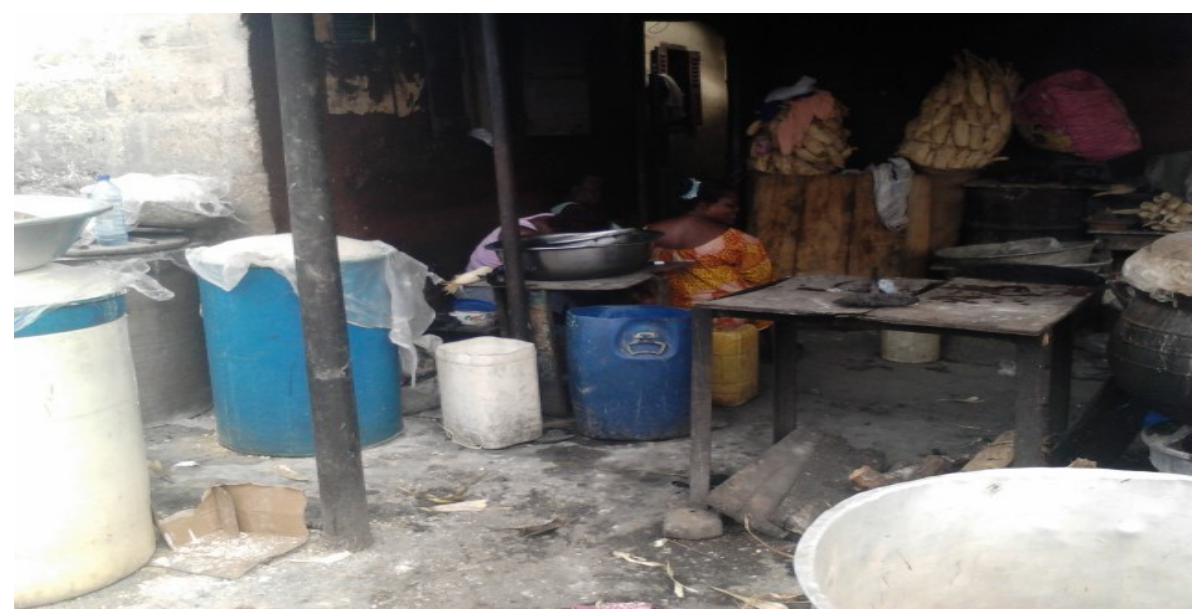

Picture 3: More utensils with corn dough

Figures 4.1, 4.2 and 4.3 depicts the kind of surroundings the people of Bukom lives in and also how they prepare the kenkey. They eat some and sell the remaining for income to support their families

Besides kenkey making, others are involve in fish mongering activities as their main source of sustenance
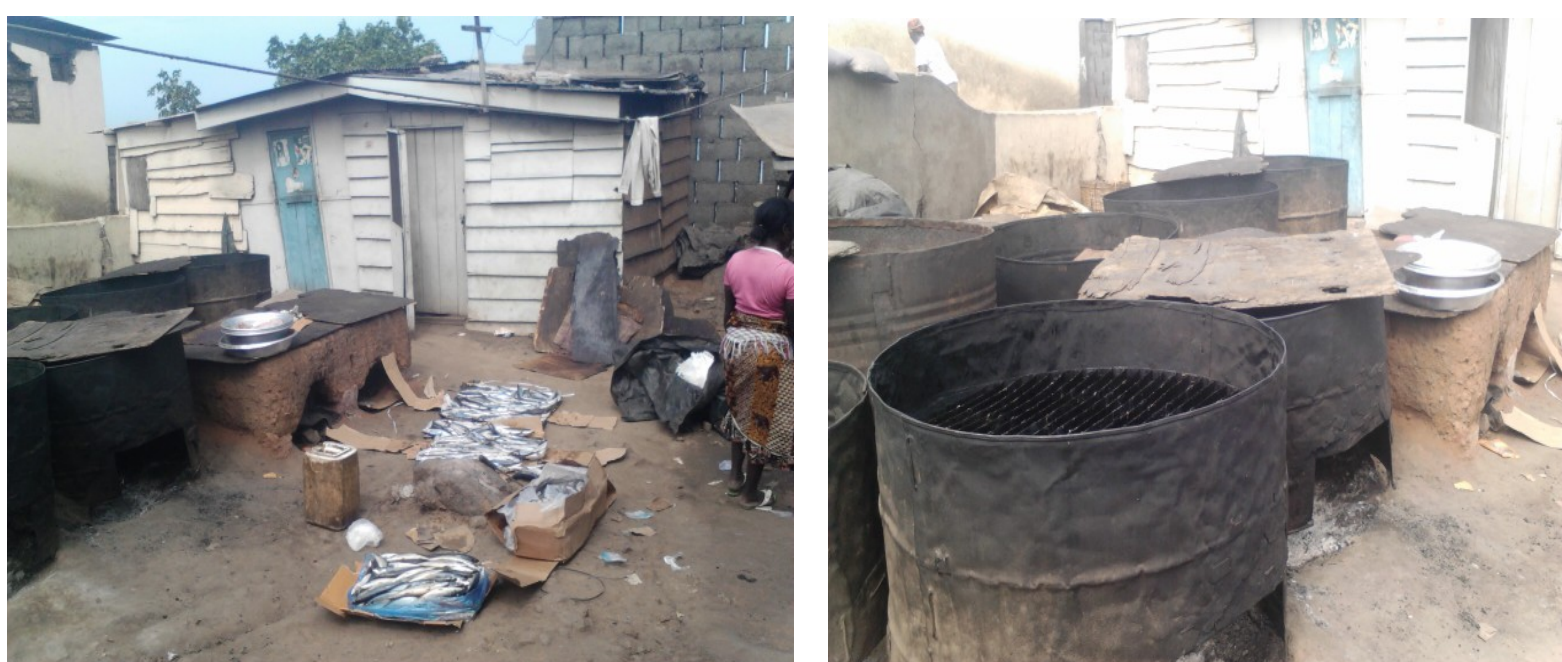

Picture 4: A fish monger drying her fish

Picture 5: Equipment used for steaming fresh fish

All the fish mongers use the crude method of steaming their fish as can be seen in Picture 4 and 5. This method possesses negative health and environmental issues.

Picture 6 and 7 below show a general overview of the coastal zone of Bukom and the kind of activities taking place and also depicts a high level of human invasion of the coastal zone. 

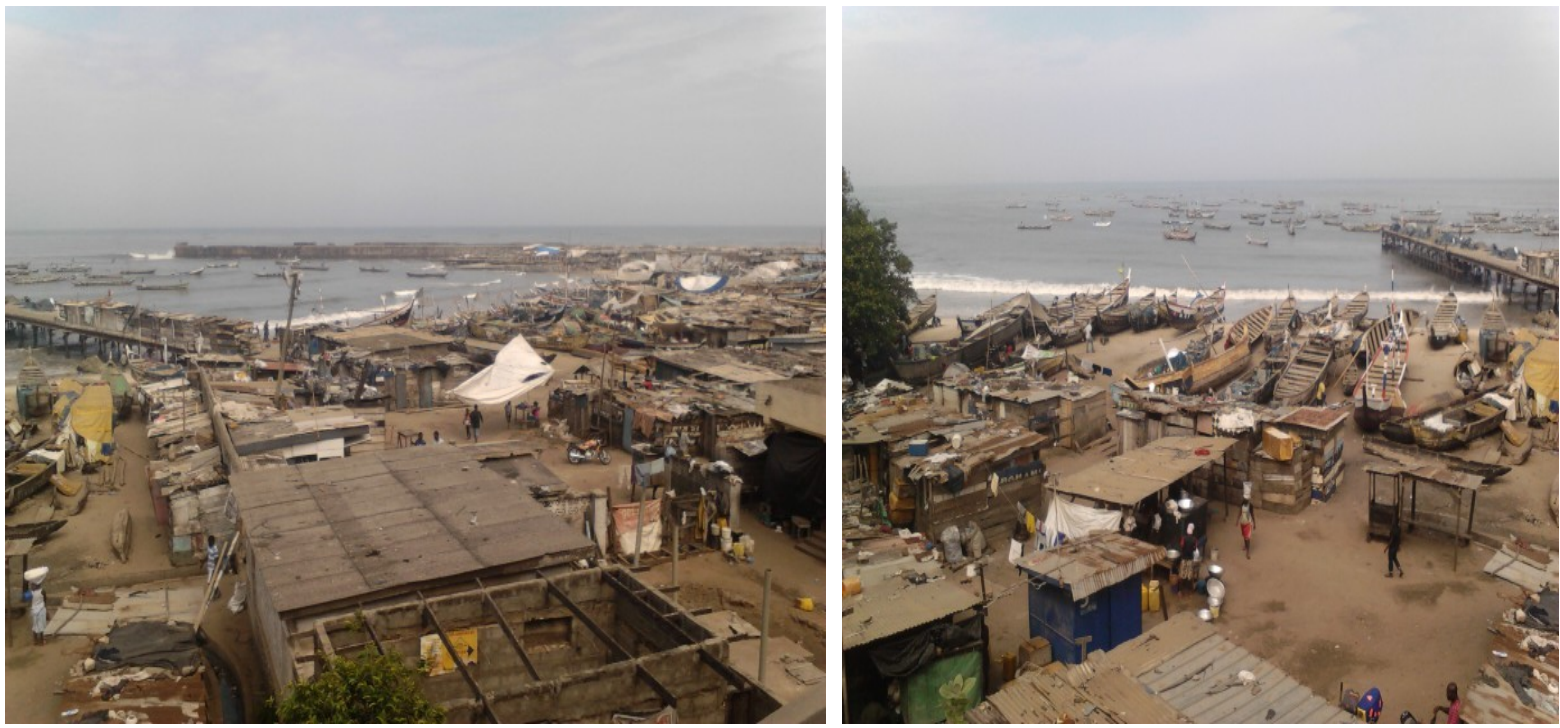

Picture 6: An overview of activities along the coast of Bukom

Picture.7: Human activities along the coast of Bukom

The coast is surrounded by wooden structures use to sell various items including kenkey and fish. This area is basically a no-man's land where everybody does whatever pleases them. This scenario is a confirmation of Gareth Hardin's idea of common resource usage in his book entitled "The Tragedy of the Commons" (Harding, 1968). Once there is a common resource it tends to be over-exploited to the point or level of total destruction if it is not controlled.

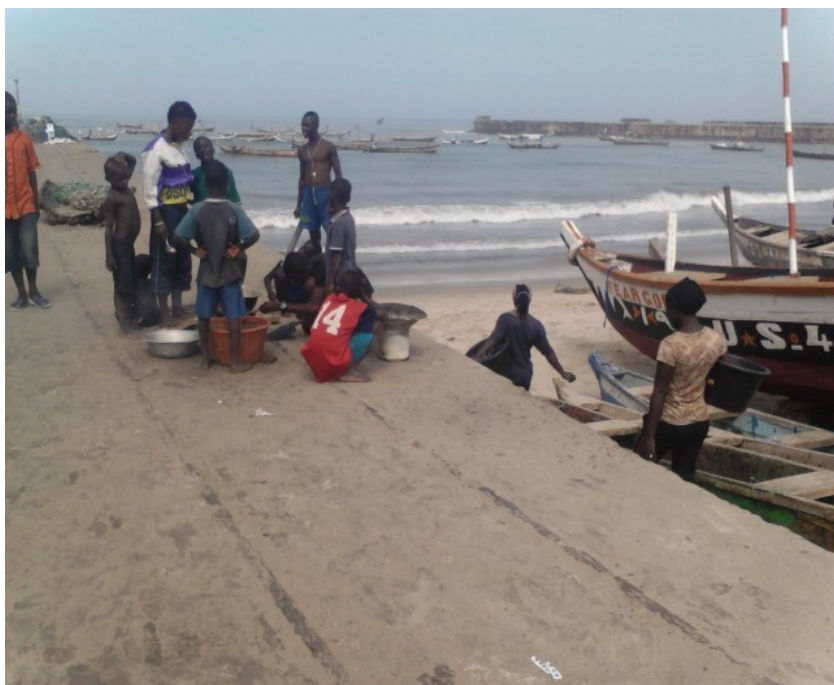

Picture 8: Kids frying fish along the sea

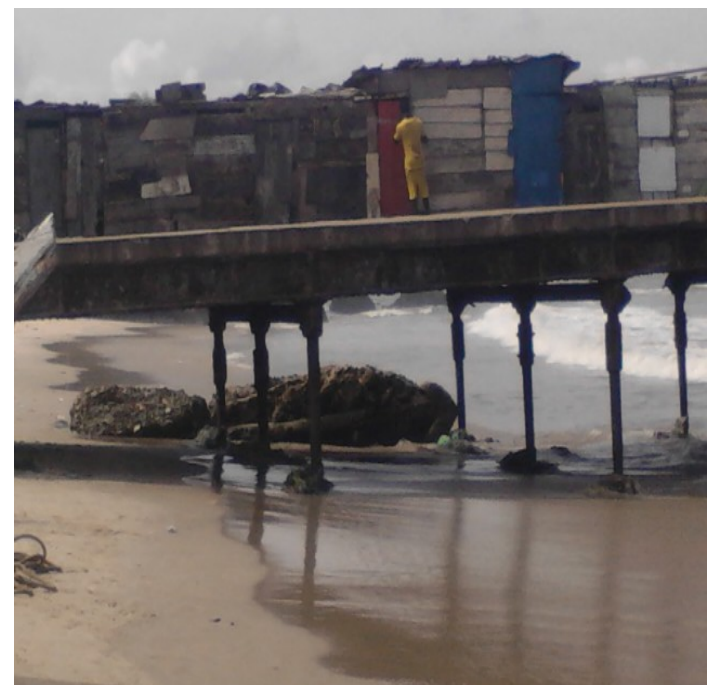

Picture .9: Wooden houses built along the bank of the sea of Bukom

\section{Results And Discussion}

The case study above is an indication of how badly Ghana's coastal zone is over exploited. According to Owusu-Ansah (1994), the percentage rate of rural-urban migration in Ghana in 1970 was estimated to be 28 per cent, this increased to 32 per cent in 1984 and further increased to 33 per cent in 1992. The rate of urbanisation also varies from one district to another with the Accra District of the Greater Accra Region having the highest urbanization rate of 83 per cent I interviewd 260 local residents of different age groups. 
Below is a summary of my case study

\begin{tabular}{|l|l|l|l|l|l|}
\hline Age Group & Num of male & Percentage of males & $\begin{array}{l}\text { Number of } \\
\text { Females }\end{array}$ & Percentage of females & Total percentage of \\
\hline $15-25$ & 23 & $\mathbf{8 . 8 5}$ & 10 & $\mathbf{3 . 8 5}$ & 12.70 \\
\hline $25-35$ & 30 & $\mathbf{1 1 . 5 4}$ & 22 & $\mathbf{8 . 4 6}$ & 20 \\
\hline $35-45$ & 45 & $\mathbf{1 7 . 3 1}$ & 27 & $\mathbf{1 0 . 3 8}$ & 27.69 \\
\hline $45-55$ & 66 & $\mathbf{2 5 . 3 9}$ & 37 & $\mathbf{1 4 . 2 3}$ & 39.62 \\
\hline TOTAL & $\mathbf{1 6 4}$ & $\mathbf{9 6}$ & & \\
\hline
\end{tabular}

Most of the residents of Bukom as interviewed claim that have been lining in the town for all their lives. Their main source of income is fishing and fish mongering using crude method of fishing. The age group $45-55$ claimed they starting fishing when they were about 7 years of age. They have been using the old crude method of fishing as their parents did.

Those aged $15-25$ are all engaged in the same crude method of fishing using boats and nets.

The fishing activity in this town is not sustainable in that they harvest both fingerlings and fry. This practise will automatically replenish all the fish stock in the sea.

From Picture 9, it can also be seen that, some of the local folks have invaded the sea shore by putting up buildings along the shores.

These activities enumerated above are very unhealthy to Ghana's coast and policies must be promulgated and implemented as soon as possible to avoid future catastrophy.

As have been stated above, Ghana has no specific coastal zone policy, however there are other policies that indirectly addresses coastal zone management issues. These policies were evelauted to test its effectiveness. Herein the results

\begin{tabular}{|c|c|c|c|c|}
\hline \multicolumn{5}{|l|}{ THEME } \\
\hline \begin{tabular}{l|l} 
Evaluation Criteria \\
\end{tabular} & A & $\mathrm{B}$ & $\mathrm{C}$ & $\mathrm{D}$ \\
\hline \multicolumn{5}{|l|}{ KEY CONCEPTS } \\
\hline Does the policy have the status it requires for success? & & $\sqrt{ }$ & & \\
\hline Are sufficient resources available for implementation? & & & & $\sqrt{ }$ \\
\hline Do compliance instrument exist? & & $\sqrt{ }$ & & \\
\hline Is the policy consistent with higher -level policy? & $\sqrt{ }$ & & & \\
\hline Does policy provide a framework for interaction? & $\sqrt{ }$ & & & \\
\hline Does policy promote co-operation? & & $\sqrt{ }$ & & \\
\hline Are there indicators that interaction exists? & & $\sqrt{ }$ & & \\
\hline Does policy promote stakeholder participation? & $\sqrt{ }$ & & & \\
\hline Does the policy promote education? & & $\sqrt{ }$ & & \\
\hline Is the policy implemented? & & & $\sqrt{ }$ & \\
\hline Has the policy improve the management of resources? & & $\sqrt{ }$ & & \\
\hline Has the policy reduce conflict of use? & & $\sqrt{ }$ & & \\
\hline Are the public satisfied? & & & $\sqrt{ }$ & \\
\hline $\begin{array}{l}\text { Have indicators of success been identified and are they being used? e.g.: comparison with known } \\
\text { (baseline) situation: } \\
\text { Improvement to water quality } \\
\text { Improved biodiversity } \\
\text { Improved habitat protection }\end{array}$ & & $\sqrt{ }$ & & \\
\hline
\end{tabular}

\section{Source: Adopted from Boateng, 1996:10}

Ghana has seen an improvement in its coastal and marine zone policies with the enactment of the various policies enumerated above. The main problem that Ghana is facing in terms of coastal and marine zone policy is the implementation of these policies as can be seen in TABLE 2.1: highlighted in red on the evaluation table above. This was noticed by the then Minister of Environment and Science, Honourable Christiana Churcher in 2006. According to Churcher, major problem Ghana is facing in terms of implementation of coastal and marine zone policies is inadequate funds. Though inadequate funds may be an important component, there are other factors preventing Ghana from implementing its coastal and marine zone protection policies as such lack of political will from out governments.

\section{The Way Forward}

This paper has reviewed Ghana's coastal zones and various policies and legislations in place that seeks to protect the general coastal environment of Ghana. An overview of the level of threat the coast is facing and will be facing in the next few years have also been analysed. In this section, possible solutions that can help avert coastal zone destruction will be discussed.

It is clear that there is no Integrated Coastal Zone Management Policy in Ghana. This is due to lack of political will on the part of government and government institution as they have different priority sectors of development to address. Stakeholders such as the Environmental Protection Agency and other Nongovernmental 
Organisation have to put pressure on government to speed up the process of promulgating and approving the draft Coastal Management Policy. The country's coastal zones are facing a serious environmental threat so coming up with a policy that will address the coastal zone problems will be the right remedy for the protection of the already degenerated coastal zones of Ghana.

An interesting point that has been discussed in this paper is that Ghana has problem with implementing policies that seeks to protect the country's coastal zones. This was confirmed in an address delivered on behalf of the then Environment Minister, Madam Christiana Churcher in 1996. According to Churcher, the problem with policy implementation in Ghana is unavailability of funds (Churcher, 1996). There is the need for the government through the Ministry of Environment, Science, Technology and Innovation to make adequate funds available to the EPA. The EPA being the policy implementing organ of the Environment Ministry will be adequately empowered when they have funds, as this will enable them recruit qualified and experience staff and to train old staffs . This will enable the EPA be in a position to enforce policies in Ghana that seeks to protect coastal zones of the country.

In Ghana District Assemblies are expected to come up with specific policies to protect their coastal zones, their policies are made available to the Municipal Assembly, from the Municipal Assembly, the policies are send to the Environmental Ministry. The Ministry of Environment then seek the services of the EPA. Comanagement has been shown to be an effective tool that better protect natural resources. According to Hara (2003) "Co-management is a type of collaborative institutional and organisational arrangement between government, user groups and stakeholders for effective management of a define resource". An important element in co-management is the involvement of local communities in decision-making. In Ghana, there has to be a good co-existence between District Assemblies, Municipal Assemblies, Ministry of Environment, EPA, NGO's, stakeholders and local coastal communities. With this co-ordination in place, there will be an improvement in the protection of the country's coastal zones.

The best investment in life is to invest in human beings. Educating local residents of coastal communities in Ghana such as Bukom will be good incentive that can help protect the Country's coastal zones. Most coastal residents are poor and make their living from fishing and fish mongering. Educating them will enlighten them on effects of bad fishing and ways to fish sustainably in order to protect the coastal zone. Fish communities have to be educated to use modern and highly sophisticated method of fishing that will not harm the environment and deplete the fish stocks. Alternative source of employment will ease pressure on the ocean and this has to be made known to fishing communities.

\section{Conclusion}

Ghana has no specific policy on Integrated Coastal Management however there are other policies that seek to protect the country's coastal zones. Institutions responsible for implementing and enforcing coastal management policies in Ghana were examined in this paper. Policies that aim at protecting the country's coastal zones were evaluated and it was found that these policies are effective in that it adheres to principles of Agenda 21. The shortcomings of these policies have to do with implementation. Former Environment and Science Minister, Madam Christiana Churchur in 1996 stated that policy implementation has been ineffective in Ghana due to the lack of funds

Ghana's coastal and marine zones are being destructed by many factors such as resource over-use, solid waste and general sanitation problem, high pollution index and many more. Cause of these environmental problems is high coastal population. It is estimated that 25 per cent of the total population of Ghana are resident along the coast. These factors are good reason for the country to promulgate appropriate and specific coastal zone management policies.

In the course of this paper, there was an overview of a typical coastal community in Ghana called Bukom. It was found that the major occupation of the Bukom people is fishing and fish mongering. It was also found that the coast zone of this community is subjected to negative practises.

Ghana is endowed with natural resources, the onus lies on the authorities and general population to protect these natural resources to ensure it is well managed for present and future generation. Gareth Hardin said in his book "The Tragedy of the Commons" that any resource that people have equal access to tend to be overexploited. In order to conserve and protect Ghana's coastal zones therefore, there have to be will be appropriate coastal zone management policies that will address coastal zone issues.

Environmental Protection Agencies, stakeholders as well as Nongovernmental Agencies have to mount pressure on Government to ensure speedy process of passing the Integrated Coastal Management Policy currently before cabinet. With pragmatic measures in place, Ghana's coastal zone will be protected and safe for many generations.

Ghana derive many benefits from the coastal zone there is therefore the need for an effective policy that will protect the coastal zone to ensure it is not depleted beyond repairs. 
An approached that can be applied which has been found to be useful in most environmental policy instrument is the application of either mandatory policies or economic instrument (Connelly et. al., 2003;157-186).

\section{Bibliography}

[1]. Armah, A. K. and Amlalo, D.S. 1998. Coastal Zone Profile of Ghana. Ministry of Environment, Science \& Technology/Large Marine Ecosystems Project of the Gulf of Guinea.

[2]. Berkes, F. 1989. Common property resources: Ecology and community-based sustainable development. London: Earthscan

[3]. Boateng, I. 1996. Policy Process in Coastal and Marine Resource Management in Ghana. Munich, Germany, pp10.

[4]. Brown, K., Tompkins, E.L. and Adger, N. 2002. Making Waves: Integrating coastal conservation and development. London: Earthscan.

[5]. Centre for Ocean Management Studies. 1981. Comparative Marine Policy: University of

[6]. Rhode Island. New York: Praeger Publishers.

[7]. Churcher, C. 2006. The Speech Delivered By Honourable Minister Of Environment and Science, Ghana at The High Level Panel Meeting on Linking National and Regional Efforts in Ocean and Coastal Management: African Perspectives at The 3rd Global 2006. [Online] Available at: http://www.globaloceans.org/globalconferences/2006/pdf/albertowususarpong. Pdf. (accessed 3 June 2013).

[8]. Cicin-Sain, B. 1993. Sustainable Development and Integrated Coastal Management. Ocean and Coastal Management. 21 , 11 -43.

[9]. Clark, J.R. 1996. Coastal Zone Management Handbook. London: Lewis Publishers.

[10]. Connelly, J. and Smith, G. 2003. Choosing the means in Politics and the Environment. London: Routledge. pp 157 - 186

[11]. Creswell, J. W. (1994). Research Design:qualitative and quantitative approaches. London: SAGE Publications.

[12]. Crooks, S. and Turner, R.K. 1999. Integrated coastal management: sustaining estuarine natural resources. Advances in Ecological Research. 29, 241-289.

[13]. Dudley, G. 1984. Implementation Dynamics and Discontinuities within the 'Imperfect'

[14]. policy process. Strathclyde, Department of Politics, University of Strathclyde.

[15]. Ghana Statistical Service, 2010. Summary report of final results. 2010 Population and Housing Census. Accra Ghana. [online] Available at http://www.statsghana.gov.gh/docfiles/2010phc/census10 Summary report of final results.pdf (accessed 4 June 2013).

[16]. Hara, M. 2003. Co-management of Natural Resources: Theory and the Attendant Assumptions. In Hauck M \& Sowman M (eds), Waves of Change - Coastal and Fisheries Co-management in Southern Africa. Cape Town: UCT Press. pp 13-36.

[17]. Hardin, G. 1968. 'The Tragedy of the Commons'’. Science 162 (3859): 1243 - 1248

[18]. Hia-Eng, C. 1993. Essential Elements of Integrated Coastal Zone Management. Ocean and Coastal Management. 21, 81-108

[19]. Biraben, J-N. 1980. “An Essay Concerning Mankind's Evolution'’. Population Selected Papers. Vol. 4, pp 1-13. Original paper in French.

[20]. Juma, C. and Clark, N. 1995. Policy Research in Sub-Saharan Africa: An Emploration.

[21]. Public Administration and Development. Vol. 15, pp $121-127$

[22]. Kay, R. and Alder, J. 1999. Coastal Planning and Management. London: E \& FN Spon.

[23]. Ketchum, B.H. 1972. The water's edge: critical problems of the coastal zone. In: Coastal Zone Workshop, 22 May-3 June 1972 Woods Hole, Massachusetts. Cambridge: MIT Press.

[24]. Ly, C.K. 1980. The role of the Akosombo Dam on the Volta River in causing coastal

[25]. erosion in Central and Eastern Ghana (West Africa). Marine Geology. 37: 323-332.

[26]. Masselink, G. and Hughes, M. 2003. Introduction to Coastal Processes and Geomorphology. London: Hodder Arnold.

[27]. Nakamura, R.T. 1987. The Textbook Policy Process and Implementation Research. Review of Policy Research. Vol 7, Issue 1, pages 142-154, September 1987.

[28]. US Census Bureau - World POP Clock Projection. July 2012 - July 2013 data. Conference On Oceans, Coastal And Islands January 23 - 28, 2006, Retrieved July 01.

[29]. Preskill, H. 2007. "Evaluation's second act': A spotlight on learning. Paper presented at the 2007 Annual Conference of the American Evaluation Association, Denver, Colorado.

[30]. Organisation for Economic Co-operation and Development (OECD). 2007. African Economic Outlook 2007 - Ghana Country Note (PDF). Retrieve 2008-03-25., p. 294

[31]. Owusu-Ansah, D. 1994. "Urban-Rural Disparities', A country study: Ghana (Library of Congress Federation Research Division (November 1994).

[32]. Towards an Integrated Coastal Zone Management Strategy for Ghana (May, 1996). Environmental Protection Agency, Ghana. Report based on consultations of stakeholder workshops at the central and district level held in Ghana.

[33]. Trochim, W.M.K. 2009. "Evaluation policy and evaluation practice". In W.M.K. Trochim,

[34]. M. M. Mark, \& L. J. Cooksy (Eds.), Evaluation policy and evaluation practice. New Directions for Evaluation, 123, 13-32.

[35]. United Nations. 1999. Ghana National Committee for the Implementation of Agenda 21. [Online] Available at:

[36]. http://www.un.org/esa/agenda21/natlinfo/countr/ghana/eco.htm

[37]. United Nations. 2006. Ocean and the Law of the Sea. [Online] Available at: http://www.un.org/depts/los/convention_agreements/covention_overview_conventio.htm (accessed 3 June 2013).

[38]. World Bank. 1998. Integrated Coastal Zone Management Strategy for Ghana. London: World Bank.

[39]. Williams, A. and Micallef, A. 2009. Beach Management: Principles and Practice. London: Earthscan.

[40]. World Commision on Environment and Development. 1987. Towards Sustainable future, "Our common future". New York: Oxford University Press. 